\title{
Kualitas Fisika-Kimia Air di Areal Budidaya Desa Kaima, Eris dan Toulimembet, Kabupaten Minahasa, Provinsi Sulawesi Utara
}

\section{Physical-Chemical Quality of Water at Fish Farming Area in Kaima, Eris and Toulimembet Villages, Regency of Minahasa, North Sulawesi Province}

\author{
Zainal M. De Breving, Robert J. Rompas
}

\begin{abstract}
Water physical-chemical quality at fish farming area in Kaima, Eris and Toulimembet villages around Lake Tondano was observed. Water quality parameters including temperature, $\mathrm{pH}$, brightness and dissolved oxygen were measured in situ. Observation was conducted at three stations, which were waters around Kaima, Eris, and Toulimembet villages. Measurement was carried out at 2-points at each station, where appointing of both points was based on the consideration of the activities of fish farming and settlement layout. Point-1 represented the activities of fish farming whereas point-2 represented the settlement activity. Data were collected at one week interval. Results showed that water temperature ranged from $26-27{ }^{0} \mathrm{C}$; brightness was above $2 \mathrm{~m}$; dissolved oxygen ranged from 2.5 - 8.3 ppm and pH ranged from 7,9 - 8,7. Based on the water quality criteria for aquaculture, water quality parameters on fish farming area in Kaima, Eris and Toulimembet, were still suitable for fish farming activities.
\end{abstract}

Keywords: Lake Tondano, water quality, fish farming

\section{PENDAHULUAN}

Potensi sumber daya perikanan Indonesia didasarkan pada 2 sumber yakni, perikanan tangkap dan perikanan budidaya. Produksi ikan Indonesia pada tahun 2004 mencapai 6 juta ton, yang terdiri dari atas 4,1 juta ton hasil tangkapan ikan laut, 0,5 juta ton hasil tangkapan ikan di perairan umum, dan 1,4 juta ton berasal dari usaha budidaya. Sementara nilai produksi budidaya tersebut berasal dari 3 sumber utama yakni, 0,7 juta ton hasil budidaya laut, 0,4 juta ton hasil budidaya perikanan tambak di perairan payau dan 0,3 juta ton dari budidaya perairan umum. Nilai produksi perikanan budidaya sebesar 1,4 juta ton menunjukkan bahwa tingkat pemanfaatan potensi perikanan budidaya baru mencapai sekitar 2,4\%. (Kordi, 2009). Oleh karena itu perlu adanya

peningkatan pemanfaatan lahan yang memiliki potensi untuk mengembangkan usaha perikanan, dimana salah satunya adalah perairan danau. Danau adalah wilayah yang digenangi badan air sepanjang tahun yang terbentuk secara alami karena gerakan kulit bumi, sehingga bentuk dan ukurannya bervariasi (Kordi, 2008). Danau Tondano tergolong danau terbesar di Sulawesi Utara yang sekarang ini banyak mendapat perhatian dari berbagai kalangan karena ekologinya mulai terganggu seperti terjadinya proses degradasi yang mengakibatkan proses pendangkalan, penurunan debit air, banjir, gejala eutrofikasi dengan pertumbuhan eceng gondok yang tidak terkendali, terganggunya kualitas air dan peningkatan tingkat mortalitas ikan 
Kualitas air dalam budidaya perairan adalah suatu faktor pembatas. Biota budidaya tumbuh optimal pada kualitas air yang sesuai dengan kebutuhannya, oleh karena itu kualitas air harus diperhatikan dan tetap terjaga. Melihat begitu pentingnya peranan kualitas air maka perlu kiranya dilakukan observasi terhadap parameter kualitas air di Danau Tondano, yang merupakan salah satu sentra budidaya ikan air tawar di Sulawesi Utara.

\section{Tujuan dan Manfaat}

Observasi lapangan ini bertujuan untuk mengetahui kualitas fisika-kimia air lokasi budidaya di Danau Tondano yang meliputi suhu, derajat keasaman $(\mathrm{pH})$, kecerahan dan oksigen terlarut (DO).

\section{Tempat dan Waktu}

Observasi lapangan ini dilaksanakan di Danau Tondano, yakni Desa Eris Kecamatan Eris, Desa Kaima Kecamatan Remboken dan Desa Toulimembet Kecamatan Kakas sejak tanggal 28 April sampai 23 Juni 2012.

\section{BAHAN DAN METODE}

Pengamatan dilakukan pada 2 titik yang telah ditentukan berdasarkan pertimbangan aktifitas budidaya dan letak pemukiman, dengan metode pengukuran secara in situ atau pengukuran langsung dilapangan, dalam hal ini lokasinya di Danau Tondano. Berikut cara pengukurannya:

\section{Parameter Fisika}

Suhu

Alat yang digunakan untuk mengukur suhu adalah alat pengukur digital, merek HANNA HI-9146. Cara menggunakan, pertama-tama tekan tombol on, selanjutnya tekan tombol mode untuk memilih intrument suhu. Kemudian elektrodanya dicelupkan kedalam perairan, setelah beberapa menit, catat bila angka sudah terlihat stabil pada layar.

Kecerahan:

Kecerahan diukur dengan menggunakan alat Secchi disk. Caranya alat tersebut dicelupkan kedalam perairan secara perlahan sampai alat itu tidak kelihatan, kemudian pada tali pengukur diberi tanda dan diukur tanda kedalaman tali Secchi disk tersebut.

\section{Parameter Kimia}

Oksigen terlarut (DO) :

Pengukuran oksigen terlarut menggunakan alat pengukur digital sama yang digunakan untuk suhu, hanya saja untuk oksigen terlarut perlu dikalibrasi. Cara menggunakannya, tekan tombol on lanjut tekan tombol mode untuk memilih intrument dissolved Oxigen, kemudian kalibrasi. Kalibrasi ini perlu dilakukan setiap kali berpindah stasiun/titik pengukuran.

Derajat keasaman $(\mathrm{pH})$ :

Alat yang digunakan untuk mengukur $\mathrm{pH}$ adalah HANNA $\mathrm{pH}$ meter digital, caranya celupkan elektroda ke dalam perairan kemudian tunggu sampai angka pada monitor stabil dan dicatat.

\section{Analisa Data}

Data hasil observasi ditabulasi, dan dibandingkan dengan baku mutu air untuk untuk Budidaya Perairan.

\section{HASIL DAN PEMBAHASAN}

Hasil pengamatan kualitas fisikakimia air pada areal budidaya di danau Tondano (lihat pada tabel) menunjukkan bahwa:

Suhu

Kisaran suhu optimal bagi kehidupan ikan di perairan tropis adalah 28 $32^{0} \mathrm{C}$. Pada kisaran tersebut 
konsumsi oksigen mencapai 2,2 $\mathrm{mg} / \mathrm{g}$ berat tubuh-jam, dibawah suhu $25^{\circ} \mathrm{C}$, konsumsi oksigen mencapai $1,2 \mathrm{mg} / \mathrm{g}$ berat tubuh-jam, sedangkan pada suhu $12-18^{0} \mathrm{C}$ mulai berbahaya bagi ikan, di bawah $12^{\circ} \mathrm{C}$ ikan tropis mati kedinginan. Secara teoritis, ikan tropis masih hidup normal pada suhu $30-35^{0} \mathrm{C}$ kalau konsentrasi oksigen terlarut cukup tinggi (Kordi dan Tancung, 2005). Data pada tabel menunjukkan suhu air berkisar $26-27^{0} \mathrm{C}$, ini masih dalam kisaran layak untuk pertumbuhan ikan.

\section{Kecerahan}

Kecerahan merupakan salah-satu faktor pembatas untuk proses fotosintesis dalam suatu ekosistem. Plankton di perairan berperan sebagai produktifitas primer perairan. Blooming plankton akibat penyuburan yang tak terkendali pada suatu perairan, akan berbahaya untuk perairan itu sendiri, dan ini dapat terjadi jika kecerahan sudah kurang dari $25 \mathrm{~cm}$. Kecerahan yang baik bagi usaha budidaya ikan berkisar 30 - 40cm, jika diukur menggunakan Secchi disk (Kordi dan Tancung, 2005). Untuk kecerahan Desa Eris Kecamatan Eris mencapai kedalaman sampai $2 \mathrm{~m}$, bahkan di Desa Kaima dan Desa Toulimembet kecerahannya $>2 \mathrm{~m}$. Hasil pengukuran menunjukkan bahwa ke tiga Desa memiliki tingkat kecerahan yang sangat baik untuk kegiatan budidaya ikan.

\section{Parameter Kimia}

Oksigen terlarut (DO)

Sumber utama oksigen dalam suatu perairan berasal dari suatu proses difusi dari udara bebas dan hasil fotosintesis organisme yang hidup dalam perairan tersebut (Effendi, 2003). Konsentrasi minimum spesies biota budidaya untuk hidup dengan baik adalah 5 ppm. Dibawah 4 ppm beberapa biota budidaya mampu bertahan hidup, tetapi nafsu makan mulai menurun. Untuk itu, konsentrasi oksigen yang baik dalam budidaya perairan adalah antara 5 - 7 ppm (Kordi dan Tancung, 2005). Pada pengukuran oksigen terlarut terlihat perbedaan yang cukup menonjol antara titik A dan B. Pada titik B kadar oksigen terlarut sangat rendah hal ini dikarenakan tingkat kepadatan dari eceng gondok sehingga menghalangi penetrasi cahaya matahari. Namun pada Desa Toulimembet penyebaran eceng gondok cukup luas di areal budidaya, sehingga kadar oksigen terlarut pada titik A dan B di Desa Toulimembet perbedaannya tidak jauh.

\section{Derajat Keasaman (pH)}

Untuk biota budidaya air tawar $\mathrm{pH}$ dibawah 4,5 air bersifat racun bagi ikan sedangkan 5 - 6,5 pertumbuhan ikan terhambat, ikan sensitif terhadap bakteri dan parasit. Pertumbuhan ikan yang baik dengan nilai $\mathrm{pH}$ 6,5 - 9,0 jika diatas 9,0 pertumbuhan ikan terhambat. Atas dasar ini, maka usaha budidaya perairan akan berhasil dengan baik dengan $\mathrm{pH}$ antara 6,5 - 9,0 dengan kisaran optimal adalah 7,5 - 8,7 (Kordi dan Tancung, 2005). Hasil pengukuran $\mathrm{pH}$ pada ditiga Desa, nilai $\mathrm{pH}$ terendah 7,9 pada titik $\mathrm{B}$ (aktifitas pemukiman Desa) di Desa Kaima dan nilai $\mathrm{pH}$ tertinggi 8,7 pada titik B di Desa Eris, artinya $\mathrm{pH}$ berada pada kisaran optimal.

Dari hasil pengamatan di Danau Tondano pada tiga Desa suhu air berkisar 26 - $27{ }^{\circ} \mathrm{C}$ sedangkan kecerahan pada Desa Eris mencapai kedalaman sampai $2 \mathrm{~m}$, bahkan pada Desa Kaima dan Desa Toulimembet kecerahannya diatas $2 \mathrm{~m}$. 
Tabel. Hasil pengukuran Parameter Kualitas air secara In-situ

\begin{tabular}{|c|c|c|c|c|c|c|c|c|c|c|c|c|}
\hline \multirow{2}{*}{ Parameter } & \multicolumn{4}{|c|}{ ERIS } & \multicolumn{4}{|c|}{ KAIMA } & \multicolumn{4}{|c|}{ TOULIMEMBET } \\
\hline & A & B & A & B & A & B & A & B & A & B & A & B \\
\hline Suhu $\left({ }^{0} \mathrm{C}\right)$ & 27 & 27 & 27 & 26 & 27 & 27 & 27 & 27 & 26 & 26 & 27 & 27 \\
\hline Kecerahan (m) & 2 & 2 & 2 & 2 & 2,5 & 2,5 & 2,5 & 2,5 & 2,5 & 2,5 & 2,5 & 2,5 \\
\hline Oksigen terlarut (ppm) & 8,0 & 3,2 & 7,9 & 2,5 & 8,2 & 2,9 & 8,3 & 3,6 & 6,2 & 4,1 & 6,6 & 4,5 \\
\hline $\mathrm{pH}$ & 8,6 & 8,7 & 8,4 & 8,6 & 8,3 & 8,4 & 8,0 & 7,9 & 8,3 & 8,0 & 8,1 & 8,1 \\
\hline
\end{tabular}

Ket: A: Titik pada aktifitas Budidaya ikan; B: Titik pada aktifitas pemukiman desa

Hasil menunjukkan bahwa suhu dan kecerahan berada pada kisaran yang baik untuk pertumbuhan ikan.

Pada pengamatan oksigen terlarut terlihat perbedaan yang cukup menonjol antara titik A dan B, titik A mewakili aktifitas Budidaya ikan dan titik B mewakili aktifitas pemukiman Desa. Pada titik B kadar oksigen terlarut sangat rendah hal ini dikarenakan tingkat penyebaran dan kepadatan dari eceng gondok sehingga menghalangi penetrasi cahaya matahari. Namun pada Desa Toulimembet penyebaran eceng gondok cukup luas pada areal budidaya akibatnya kadar oksigen terlarut pada titik A dan B di Desa Toulimembet perbedaannya tidak begitu jauh. Untuk pengukuran $\mathrm{pH}$ pada ketiga Desa $\mathrm{pH}$ terendah 7,9 pada titik B di Desa Kaima dan pH tertinggi 8,7 pada titik B di Desa Eris, artinya $\mathrm{pH}$ berada pada kisaran optimal.

Berdasarkan hasil pengamatan terhadap parameter kualitas air di Danau Tondano pada tiga Desa, yakni Desa Eris Kecamatan Eris, Desa Kaima Kecamatan Remboken dan Desa Toulimembet Kecamatan Kakas dapat disimpulkan bahwa pengukuran kualitas air untuk parameter Fisika-Kimia hasilnya masih memenuhi syarat bagi pertumbuhan ikan. Namun keberadaan eceng gondok masih memberikan pengaruh terhadap kadar oksigen terlarut.
Sumber utama oksigen dalam suatu perairan berasal dari suatu proses difusi dari udara bebas dan hasil fotosintesis organisme yang hidup dalam perairan tersebut. Jika penyebaran eceng gondok makin meluas maka dapat menghambat proses fotosintesis, karena cahaya matahari terhalangi oleh padatnya eceng gondok dipermukaan perairan. Instansi pemerintah terkait diharapkan menanggulangi masalah enceng gondok bersama masyarakat setempat, seperti mengoperasikan kembali kapal pengangkut enceng gondok di Danau Tondano.

\section{KESIMPULAN}

Hasil pengamatan parameter fisika kimia air di sekitar lokasi budidaya perairan Danau Tondano, menunjukkan bahwa suhu berada pada kisaran 26 - 27 ${ }^{0} \mathrm{C}$; kecerahan berada pada level sekitar 2 m; oksigen terlarut berada pada kisaran 2.5 - 8.3 ppm and nilai pH antara 7,9 - 8,7. Berdasarkan pada baku mutu air untuk aktifitas budidaya perairan, maka perairan yang diamati yakni di desa Kaima, Eris and Toulimembet, memiliki kualitas fisika-kimia yang layak untuk budidaya perairan. 


\section{DAFTAR PUSTAKA}

Effendi, H., 2003. Telaah Kualitas Air Bagi Pengelolaan Sumberdaya dan Lingkungan Perairan. Kanisius, Yogyakarta.

Kordi, K. M., Tancung, A. B., 2005. Pengelolaan Kualitas Air. Rineka Cipta, Jakarta.

Kordi, K. M., Ghufran H., 2008. Budi Daya Perairan Buku Pertama. Citra Aditya Bakti, Bandung.
Kordi, K. M., Ghufran H., 2009. Budi Daya Perairan Buku Kedua. Citra Aditya Bakti, Bandung.

Rompas, R.M., Masengi, A.K., Pangemanan, N.P., Moningkey, R., Kawung, N., 1995. Ekologi Danau Tondano. Laporan Penelitian Fakultas Perikanan UNSRAT. Proyek Penelitian Kawasan Kritis DAS Tondano Tahun Anggaran 1995/1996 Kabupaten Minahasa, Manado. 